\title{
ALEKSANDER BOŁDYREW*
}

\section{THE BOW IN THE BORDERLAND IN THE $16^{\text {th }}$ CENTURY}

\begin{abstract}
After finishing a long-term conflict with the State of the Teutonic Order (1521, 1525), the Polish foreign policy directed its focus to the East, which resulted in the necessity to reorganise the armed forces, at least partially. It translated, among other things, into changes in the military technology. The latter, in turn, had to be gradually adapted to the unique military culture which dominated in the Eastern and South-Eastern theatre of military operations. Among many symptoms of these changes, some can be observed in the area of weaponry. This was a natural process, observed also in other territorial and temporal contexts, which normally took place after two different war customs had met. In the $16^{\text {th }}$ century Eastern and South-Eastern theatre of military operations, a perfect example is offered by the abandonment and later the return to using the bow and arrow in combat.
\end{abstract}

Keywords: history of warfare, arms and armour history, early modern history

Central locations influence the hinterland, shaping its social and economic aspects, as well as the administrative and military structure. In the case of a borderline, there is an even more interesting coincidence. Borderline areas remain under the influence of two centres which compete with each other. Additionally, if a borderline lies at the meeting of not only two conflicts but also, in a longer temporal perspective, the meeting of two cultures, the quantity and - as we should suspect - the quality of processes which take place in the area are multiplied. This is especially the case if the dispute is fuelled not only by different political, dynastical or territorial interests, but also by an admixture of ideological argument with a religious tinge (the Latin West and the „Greek” East). In such a situation, a characteristic borderline culture is born, which includes military culture. The path (method, way) to its origination is cultural diffusion, understood ex definitione as having multiple forms ${ }^{1}$.

Under normal (peaceful) conditions, the hinterland is a broadly-defined resource area for the centre ${ }^{2}$. During war, it is the centre which becomes such an area, providing resources and materials to the hinterland, and with them a sort of modus operandi, a „style of life” or even „style of usage". Then, the hinterland represents the centre as the

* Institute of History and International Relations, Faculty of History and Philology, Jan Kochanowski University, bow0@poczta.onet.pl

1 Bołdyrew 2014, 550-557.

2 Moździoch 1999, 7. vanguard of these phenomena. The direction of the movement of goods, including cultural goods belonging to the area of material culture is reversed. Thus, the peripheries of centres, that is, the Crown and Lithuania on the one hand and Muscovy on the other hand, had to function simultaneously as correlative (for the centres) borderline military subsystems and blend into a shared peripheral subsystem. This subsystem might be described as a form of adaptation to the environment, but not only the biological one (as defined by processual archaeology for example). From the point of view of contextual analysis, the described example confirms the proposition of the lack of universality of certain behaviours. This is due to the fact that each time the local "flavour" was determined by the cultural context ${ }^{3}$. In this case this context was different than the assumptions worked out during long-term military disputes with the Teutonic Order, or dynastic struggles fought in the area of Bohemia and Hungary by the Polish army.

Of course, it was not only artefacts which came to the hinterland area under threat of or engulfed in warfare. Along with them, there came an entire set of techniques of using them. However, as it was mentioned before, the hinterland participates in creating borderline culture, which is characteristic for the local conditions. Thus, since the culture is formed via cultural diffusion, it must be assumed that an equally important phenomenon is the adoption of artefacts and their usage methods from the other side. 
Only after analysing a complete set of these factors it will it be possible to draw a picture of the borderline military culture as regards the weaponry and its sets used in combat there. This military culture originated as a result of a clash of ,military traditions" from two centres with divergent and opposing political interests, which were pursued in a reciprocal conflict.

Obviously, an exhaustive analysis of this phenomenon would exceed the limits of this article. This is why this study is merely devoted to a single kind of ranged weapons, that is the bow and arrow in all its varieties identified in the borderland of the Crown, the Grand Duchy of Lithuania, the Grand Duchy of Muscovy, and Moldavia, or - in the typical language of military history - the Eastern and South-Eastern theatre of military operations during the rule of the last members of the Jagiellonian dynasty. The chronological scope of this work is arbitrary, as the discussed phenomena were shaped during a period of many years and the same may be said about their gradual disappearance. While it is possible to provide an exact date, confirmed by a written source, of the first mention of a matchlock gun in the hands of the Polish soldiers, or the moment when the gravioris armaturae type of cavalry armour was abandoned, it is hardly feasible to precisely date the process of returning to the use of bow and arrow by the soldiers of the Commonwealth in the $16^{\text {th }}$ century.

Admittedly, Stanisław Sarnicki wrote that the bow and arrow is a ,[...] famous, defensive and quick [...]" weap$\mathrm{on}^{4}$. However, we must not forget that in the conditions of the Western European style of warfare (e.g., during the so-called „Prussian war” of 1519-1521) this quick weapon could not meet the requirements of the battlefield, which was already absolutely dominated by individual and teamoperated black-powder firearms. Besides, Sarnicki added that: ,[...] jakże rusznice nastały, także jednak jego mniemanie nieco jest zniżone, bo z rusznicy jednak dalej ugodzi [...] [when the matchlock gun was introduced, the bow and arrow's importance decreased somewhat, as the matchlock gun will reach farther]"'.

It should thus be a natural consequence of hand-held guns and artillery becoming widespread that neuroballistic weapons would be abandoned. Generally, this was the case, although not for the unique area of the Eastern borderline of Poland in the $16^{\text {th }}$ century. It was there that, in accordance with the rule mentioned at the beginning of this paper, military cultures of two different centres met. A dominating feature of warfare in the East was that it was based on highly mobile light cavalry, whose tactics was adjusted to the needs of operating in vast areas. A necessity to cover impressive distances, perform rapid manoeuvres, turns or numerous dodges during combat, in order to increase the

\footnotetext{
4 Korzon 1912, 280.

5 Korzon 1912, 280.
}

distance from the enemy, promoted the formation of horse armies which suddenly appeared and disappeared in vast steppes, forests or marshlands. As a matter of fact, written sources often mention a sudden appearance of the enemy, its offensive action and response of the assaulted party only during the pursuit.

In confrontation with such an opponent, it was necessary to gradually modify one's military tradition, weaponry and tactics. In such case, it becomes reasonable to adopt the already proven solutions. As regards individual weaponry (on the part of the Polish-Lithuanian Commonwealth), one of such elements was the return to the use of the bow and arrow, which have previously been abandoned due to better functional parameters of the gun. However, in a new environment, the bow once again became equal in convenience (and mainly in it) to the gun, which was probably decisive for its common use. Numerous source references allow typological and formal questions to be clarified ${ }^{6}$, although the lack of theoretical works seriously restricts research possibilities?.

Bows appear frequently in registers of hired troops. However, army officials did not record the presence of a bow but instead used the word sahaidak, sahaid, sahai, $s a h$ or cazaŭдакъ ${ }^{8}$. This term (sajdak, sahajdak) is explicit and, as it is known, it meant a set of covers used for transporting the bow and arrows. The weapon itself was carried in a pouch (tubie) suspended from the belt or saddle, and the arrows were kept in a quiver. The record 'sajdak' ( $s a-$ hajdak) also indicates the bow type used by the so-called kozaks in the enlisted cavalry, because this way was only used for transporting Asian style bows, that is, composite recurve or double recurve bows. It is worth stressing that a schematic image of this weapon is found in one of woodcuts used as illustrations for the work by S. Herberstein 9 . This study, being the outcome of the emissary's journey to the Grand Duchy of Muscovy, was partially devoted to describing Russian customs, including the military traditions. The woodcut shows a bow pouch and an Eastern style quiver, suspended from a rope stretched between columns visible in the background. Interestingly enough, the woodcut shows a certain characteristic feature of quivers used in the East. The visible discoid bottom of the quiver made it a rigid container, which allowed a considerable quantity of arrows to be kept in $\mathrm{it}^{10}$. However, it must be noted

6 To avoid repetitions, I intentionally do not discuss already known facts about the bow in medieval and early modern Central Europe. For more information see: Werner 1967, 5-25; Werner 1974, passim; Żygulski jun. 1982, passim.

7 For other countries see Ascham 1866, passim.

8 It is stated in a slightly different way in the inventory of a Cracow burgher Jan Waxman from 1603: ,[...] łuk, sajdak i strzały [...] [the bow, sajdak and arrows]", see: Żygulski jun. $1982,261$.

9 Herberstein 1571, 156.

10 Bołdyrew 2015, 166. 
that the weapon depicted by the representative of a different Western-European culture as a typical Muscovite one, apparently got into the hands of the Polish and Lithuanian soldiers. While bows owned by Lithuanian soldiers are not surprising, their presence in the hands of Crown soldiers is the best proof for the blending of military traditions and gradual adaptation to the rules of the local battlefield, as it was implied at the beginning of this article.

A further analysis of this kind of weapon is nearly impossible on the basis of currently available written sources related to operations of the Polish or Lithuanian military in the period in question. No sources have been found so far which would clarify this issue. Therefore, it is difficult to determine whether Eastern bows were drawn with fingers or with a thumb ring, how the arm guard looked like or whether it was used at all. Not much more is known about the design of the limbs, bowstring and arrows, besides the fact that the limbs were laminated of many available organic materials. At the same time, it is not a novelty that the euphemistic term „Eastern bow” („Asian bow”) is merely a collective reference to numerous typological varieties, characteristic of different periods and regions of Asia (where the weapon itself comes from) in a broad sense, as well as the technique of using $\mathrm{it}^{11}$. One of a few noteworthy source references in this context is the description in an inventory made after the death of Stephen Bathory, which states: tubie do saidaku rozmaitemi farbami $N^{\circ} 2$, lukow tureczkich czudnijch $N^{\circ} 7$ [2 bow poaches for the sajdak painted with various colours, 7 marvellous Turkish bows $]^{12}$. This information shows that the bow poach (lubia) was painted, whereas the seven bows were referred to with a sophisticated but de facto not really meaningful term cudny (marvellous). Unfortunately, one may only guess that they were not only richly and fancifully decorated but probably also exhibited correct proportions which gladdened the eye of the owner. On another note, it is worth stressing that a stylish artefact did not necessarily provide a high practical value.

The above mentioned bows might have been presented to the king as gifts. Chroniclers of the $16^{\text {th }}$ century reported on several such occasions. Jan Dymitr Solikowski wrote an account of a Tatar mission to John of the Lithuanian Dukes, Bishop of Vilnius, who was given „two arrows from the czar"13. A quiver with arrows, was given as a gift from Hetman Jan Zamoyski to the Swedish king by Jan Ostroróg. It occurred during a meeting between John of Sweden, Duke of Östergötland and Sigismund III

11 Swoboda 2011, 21.

12 Archiwum Główne Akt Dawnych, Archiwum Skarbu Koronnego, Oddz. III, (henceforth as: AGAD, ASK) Rachunki dworskie, sygn. 2 (Central Archives of Historical Records, Crown Treasury Archives, Division III, Court accounts, sign. 2), ch. 543-543v.

13 Solikowski 1855, 213.
Vasa in August $1588^{14}$. As a matter of fact, Zamojski himself was also given a souvenir of this kind in 1595 . When camping near Cecora, he received an ambassador who: „[...] oddawszy od Sędziaka list y poselstwo sprawiwszy, oddał łuk Turecki w upominku od Sędziaka [...] [after handing over the letter from Sędziak and completing the mission, gave a Turkish bow as a gift from Sędziak]"15. The quoted examples confirm an assumption that a bow or a quiver with arrows were such valuable presents that they were often given during missions at the highest diplomatic levels. After all, we know that Solikowski reported somewhere else „bows and quivers” as elements of a very rich full dress of Polish envoys who were sent to France for arranging the conditions of Henry III of France's arrival in the Crown. Bows were thus not only gifts worthy of rulers, bishops or hetmans, but also a necessary part of dress of envoys. It is of interest that the Turkish bow was mentioned twice in the quoted sources. It is assumed that it was the shortest variety of the composite bow used in Central and Eastern Europe and in the European-Asian borderland. Laboratory studies indicated that the core of the limbs was most often made of yew, maple or osage orange ${ }^{16}$. However, it must be remembered that the contemporary term „Turkish bow" is not necessarily a synonym of the source term „Turkish.” Perhaps, at that time individual bow types were not differentiated as regards their design, but for example as regards their place of origin. Hence, the marvellous Turkish bow might just as well have been a bow brought from Turkey, but typologically - a design that is contemporarily classified as Persian or Arabian. Archers shown in the painting of „The Battle of Orsha” draw their bows so that they reach their cheekbones or ears. This allowed them to increase the length of the draw and thus the initial velocity of the arrow. But this shooting technique matches bows of Mongol origin rather than those of Turkish one, and it must be kept in mind that bows in the painting are held by soldiers of both armies. Thus, the problem does not only concern the Muscovite army, which would - to a certain degree - suggest a simple dependency consisting in the Muscovites taking over the weapon and usage techniques from the Mongols.

Of course, weapons used in warfare may have been of a slightly lower artistic or decorative value, though they probably were more efficient. An analysis of the composition of a cavalry detachment makes it possible to discuss the problem of quantity of this kind of weapon. But first, I must stress that no regularity of the occurrence of bows can be determined, for example in a temporal scale. For example, lists of 4 cavalry units with soldiers armed with bows come from 1551. In total, among 458 soldiers there were 200 men with sajdaks $-43.7 \%$. However, the picture

\footnotetext{
14 Heidenstein 1857, 287.

15 Bielski 1851, 242.

16 Gündüz and Yaman 2013, 551.
} 
was completely different at the level of individual units. In a 200-horse unit of Bernard Pretwicz, there were 94 horsemen with bows ${ }^{17}$, which makes up nearly $90 \%$ of the total number ${ }^{18}$. In another detachment, soldiers with bows constituted more than $41 \%{ }^{19}$. On the other hand, in the two latter units, i.e., those commanded by Mikołaj Sieniawski ${ }^{20}$ and Jan Ciepłowski ${ }^{21}$, there were $15 \%$ and $16 \%$ of archers respectively. However, this does not prove a gradual abandonment of the bow, as the register of the detachment commanded by Filon Kmita Czarnobylski in 1567 states that $30 \%$ of soldiers were armed with bows ${ }^{22}$, whereas the share of archers in the unit of Stanisław Dzierżanowski inspected in 1579 was nearly $24 \%{ }^{23}$. It may therefore be assumed that bows were present in a certain proportion in some units, but they did not constitute a necessary component of weaponry of any other types of army units, besides the so-called kozaks.

\section{In combat}

Bows were reported on many occasions in descriptions of clashes with Rus' forces, and then with the Grand Duchy of Muscovy or the Tatars. Even in relation to the historical context, historiographers noticed this offensive weapon. For example, in his account of the so-called Battle of the River Bug, fought by Bolesław I the Brave against the forces of Yaroslav the Wise in 1018, Marcin Bielski stated that ,[...] poczęli na się strzelać, jedni z łuków, drudzy z kusz [...] [they started to shoot at each other, some using bows, others using crossbows]". ${ }^{24}$ The mention of crossbows is a clear anachronism, but apparently, the use of neuroballistic weapons was obvious in this context for the author. Bielski also mentioned bows in the description of a battle fought by Casimir I the Restorer with the Yotvingians: „Wysadził zbrojne Niemce na przodek przeciw niezbrojnym poganom. Potkali się z obu stron mocnie, pogani z łuków, naszy z kusz strzelali na się, trwała bitwa pół dnia [He put the armed Germans to the front, against unarmed pagans. Both sides clashed strongly, the pagans using bows, our army shot crossbows. The battle lasted half $a \quad d a y]^{25}$. The bow was also present in the account of the Battle of Hundsfeld ${ }^{26}$, in the clash between Casimir II the Just and the Rus' in $1182^{27}$, or even in battles from the

17 AGAD, ASK, D. 85, sign. 56, ch. 13-21; Spieralski 1958, 76-78.

18 For a difference between registers and the actual state of the army of the Crown see: Bołdyrew 2011, $68 \mathrm{ff}$.

19 AGAD, ASK, D. 85, sign. 56, ch. 22-30.

20 AGAD, ASK, D. 85, sign. 56, ch. 36-40.

21 AGAD, ASK, D. 85, sign. 56, ch. 54-56.

22 Arheografičeskij... 1867, 214-224; Spieralski and Wimmer 1961, 76-78.

23 AGAD, ASK, D. 85, sign. 63, ch. 11v-13.

24 Bielski 1856a, 87.

25 Bielski 1856a, 108.

26 Bielski 1856a, 157.

27 Bielski 1856a, 213. period of the so-called „Great War” with the Teutonic Or$\mathrm{de}^{28}$. However, the bow became a permanent part of standard weaponry used by the Tatars. Marcin Kromer reports that during the Thirteen Years' War ,,[...] Tatary z trochą dworzan w pogonią za nieprzyjacielem wysyłają, która pogonia nieprzyjacioły do łodzi wsiadające $\mathrm{i}$ od brzegu odpychające się dojechawszy, srogą w nich klęskę siekąc i z łuków strzelając sprawiła [...] [The Tatars and some courtiers set off in pursuit of the enemy, and when the pursuit reaches the enemy upon boarding their boats, they defeat them severely with swords and bows]" ${ }^{29}$.

Several chronicle descriptions also concern the late 1480s, when John I Albert commanded the army which fought Tatar invasions. In one of skirmishes, the Tatars „[...] szeregi swoje wywodzą, a końmi nawracają według zwyczaju swego, zaczym gęstwę strzał na kształt gradu nawiasem w górę wypuściwszy, razem konie i żołnierze szkodliwie zwierzchu obrazili [...] [arrange their ranks, and turn their horses around as they usually do, and then they release a mass of arrows, like a hailstorm, severely wounding both horses and soldiers]" ${ }^{\prime 30}$. This use of bows, typical of the Tatar military, was also noticed by Marcin Bielski, who said in reference to the same events: ,[...] obyczajem swym, wystrzelili ku górze wszyscy po strzale tak, iż strzałami niebo prawie zaćmili [...] [as they have in custom, each of them shot an arrow so that they nearly clouded the sky with arrows]" 31 . In another place, M. Kromer reported that the Tatars ,[...] na ręczną wprawdzie bitwę nie bardzo nacierali, ale zaś z daleka konie zarówno jako i ludzie z łuków ustrzeliwali [...] [might not have pressed for close combat, but from afar they shot both horses and people using their bows] ${ }^{\prime 32}$. Notes of similar tone can also be found in writings by other authors ${ }^{33}$. Bernard Wapowski mentioned (in the context of the Battle of Kletsk in 1506) three horses of Michał Gliński which were sagittis confixos [pierced by arrows] $]^{34}$. However, the Lithuanians gave as good as they got:

„Tak Litwie niechcąc brodu dopuścić grad z łuków Żelazy wypuścili, aż niebo brzmi z huków, Swiszczące strzały jak deszcz zewsząd lecą pędem, Lecz Gliński rozwlekłym był Litwę sprawił rzędem. Tak im strzały Tatarskie mało zaszkodziły, A jeszcze na nich samych naszym się zgodziły [...]"35.

28 Bielski 1856a, 576

29 Kromer 1857, 1123.

30 Kromer 1857, 1306.

31 Bielski 1856a, 883.

32 Kromer 1857, 1323.

33 Stryjkowski 1846, 335, 369; Bielski 1856a, 919-920, 931932, 992, 1008, 1044; Wapowski 1874, 161, 190, 227; Decius 1901, 61, 63; Decjusz 1960, 66, 67.

34 Wapowski 1874, 68.

35 Stryjkowski 1846, 334. 
[Trying to prevent the Lithuanians from reaching the ford, they released a hailstorm of iron arrows which made the sky roar. The whistling arrows fell like rain from all directions, but Glinski scattered his men widely and the Tatar arrows did not cause much harm, and they could even be used against the attackers.]

The unpleasant experiences were used by Polish soldiers, who started using bows, as it is confirmed by the previously mentioned registers of cavalry. Besides, Łukasz Działyński reported in his account of the preparation for crossing the River Lovat near Velikiye Luki in 1576 that ,[...] trzech towarzystwa z Dymkowej roty [...] skoczyli do łuków [...] [ a company from the unit of Dymek [...] took to their bows]"36. It becomes clear once we compare it with a mention recorded several days before (16 August), when a Polish soldier, chased by Tatars, ran to a clearing where Polish infantrymen were felling trees to build a bridge. Coming closer, he shouted at them and they ,[...] do rusznic skoczyli [...] [took to their matchlock guns]" but ,[...] ognia dla rozpalenia knotów przyjść nie mogli [...] [could not light the fire for igniting their slow matches]"37. In such situations, the bow was a weapon that did not require any additional preparations, whereas hand guns, though more effective as regards their shot parameters, turned out to be useless in urgent need. Near Cecora, just after 6 October 1595, a Polish sentry unit clashed with „[...] siostrzeńcem Chana samego: y postrzelili go naszy dwa razy z łuku samego y konia [...] [the Khan's nephew himself: and our soldiers shot him twice with a bow - him and his horse]"38.

As I stressed earlier, the bow was the most effective when a large number of warriors took a shot at the same time. In such case, people and horses were expected to be hurt so the aim was taken at the mass of troops. Incidentally, such shooting was known earlier and proved to be an effective tactics for the use of personal neuroballistic weapon not only with respect to the bow. Because precise aiming was not necessary, the archer was able to shoot several times per minute. This is exactly how ranged combat must have looked like, when conducted by skilful Tatar or Muscovite archers, but probably also the Polish or Lithuanian soldiers resorted to this method. It is enough to take a look at the painting of „The Battle of Orsha”, where a host of Muscovite soldiers are visible. Among them there are mounted archers who draw their bowstrings (particularly in the upper part of the painting). Also there we can notice a Muscovite soldier who holds a bow with an arrow placed on the bowstring in his left hand (to the left of the scene with two enemy soldiers being chased).

\footnotetext{
36 Działyński 1887, 226.

37 Działyński 1887, 221.

38 Bielski 1851, 245.
}

A completely different matter is the question of defence against concentrated archery fire. Marcin Bielski mentions Marcus Antonius, who recommended „[...] zasklepić tarczami wierch wojska wszystkiego [...] [to close up with shields the topside over all the units]" in such an event ${ }^{39}$. On the other hand, it is known that Gliński „[...] rozwlekłym był Litwę sprawił rzędem. Tak im strzały Tatarskie mało zaszkodziły [scattered his men widely and the Tatar arrows did not cause much harm]". ${ }^{40}$ Perhaps both techniques were applied by soldiers who fought in the Eastern and South-Eastern theatre of military operations, but only the latter was reported in the sources as the one used in the battlefield.

As shown by the source references, the bow was also used during sieges. Marcin Bielski reports how a commander of a Livonian castle hit a Muscovite duke with an arrow from his bow during the siege ${ }^{41}$. At another occasion, during the siege of Chojnice in 1466, ,[...] puściwszy naszy kilka strzał z ogniem przyprawionych miasto zapalili tak, iż go czwarta część prawie pogorzała i szpiklerze z żywnością zgorzały [...] [having shot several incendiary arrows, they set the city on fire so that nearly one fourth of it was burnt down, as were the granaries with food]"42. This example is interesting as it shows an unusually effective handling of what might seem to be an old-fashioned weapon. There are countless other examples of the use of bows in sieges ${ }^{43}$.

This overview of source references seems to confirm the common use of the bow within the analysed temporal and geographical context. Battlefield conditions favoured the use of the weapon which, given appropriate skill, offered a possibility of an immediate shot and served well both infantrymen and mounted soldiers. Reports of bows in the hands of soldiers of virtually all armies allow for an assumption that bows were easily available, and possible supply of arrows was provided not only by purchases but via war booty. Of course, arrows did not always have appropriate technical parameters but their exchange for the proper or better ones was certainly not difficult, since a large part of soldiers usually carried arrows with them. Shooting arrows of random length and parameters must have resulted in missing the target, especially at longer distances. However, instinctive aiming probably compensated for such inconveniences to a degree, by introducing corrections when drawing the bow. It must also be kept in mind that during combat bows were aimed at the mass of troops rather than individual soldiers, which made it even easier to take a fairly accurate shot.

\footnotetext{
39 Bielski 1856b, 279

40 Stryjkowski 1846, 334.

41 Bielski 1856a, 1130.

42 Bielski 1856a, 813 .

43 Bielski 1851, 216; Bielski 1856a, 1712-1713; Wapowski
} 1874, 145; Decius 1901, 128; Decjusz 1960, 127. 


\section{Sources}

Arheografičeskij sbornik' dokumentov' otnosâsihsâ k' istorii s'everozapadnoj Rusi/Apхеографический сборникъ документовъ относящихся къ истории съверозападной Руси 4. Wilno 1867.

Ascham R. 1866. Toxophilus. The School of Shooting. London.

Bielski J. 1851. Dalszy ciag kroniki polskiej. Warszawa.

Bielski M. 1856a. Kronika polska. K. J. Turowski (ed.). Sanok.

Bielski M. 1856b. Sprawa rycerska. In: K. W. Woycicki, Archiwum domowe do dziejów literatury krajowej z rękopisów $i$ dziet najrzadszych zebrat $i$ wydat [...]. Warszawa.

Central Archives of Historical Records, Crown Treasury Archive, Division 85, sign. 56.

Central Archives of Historical Records, Crown Treasury Archive, Division 85, sign. 63.

Central Archives of Historical Records, Crown Treasury Archives, Division III, Court accounts, sign. 2.

Decius J. L. 1901. De Sigismundi regis temporibus liber 1521. W. Czermak (ed.). Kraków.

Decjusz J. L. 1960. Księga o czasach króla Zygmunta [translated by K. Kumaniecki, J. Baryń, T. Bieńkowski, G. Chilkiewicz, J. Sękowski, B. Tatarowska, C. Tworzydło, A. Wołoszyn], T. Bieńkowski (ed.). Warszawa.

Działyński Ł. 1887. Dyaryusz oblężenia i zdobycia Wieliża, Wielkich Łuk i Zawołocia od dnia 1 Sierpnia do 25 Listopada 1580 r. pisany przez [...] starostę Kowalskiego i Brodnickiego. In: Sprawy wojenne króla Stefana Batorego. Dyaryjusze, relacyje, listy i akta z lat 1576-1586. I. Polkowski (ed.). Kraków.

Heidenstein R. 1857. Dzieje polskie od śmierci Zygmunta Augusta do roku 1594 ksiag XII [translated by M. Gliszczyński] 2. Petersbug.

Herberstein S. 1571. Rerum Moscoviticarum commentarii. Bazileae.

Kromer M. 1857. Kronika polska [...] biskupa warmińskiego ksiag XXX dotad w trzech językach, a mianowicie w tacińskim, polskim i niemieckim wydana, na język polski z tacińskiego przełożona przez Marcina z Błażowa Błażowskiego. K. Pollak (ed.). Sanok.

Solikowski J. D. 1855. Krótki pamiętnik rzeczy polskich od zgonu Zygmunta Augusta, zmarłego w Knyszynie 1572 r. $w$ miesiacu lipcu, do r. 1590 [translation of the $1^{\text {st }}$ edition: W. Syrokomla]. Petersburg.

Stryjkowski M. 1846. Kronika polska, litewska, żmudzka i wszystkiej Rusi [...] vol. 2, M. Malinowski (ed.), Warszawa.

Wapowski B. 1874. Kroniki [...] z Radochoniec kantora katedr. Krakowskiego część ostatnia czasy podtugoszowskie obejmująca (1480-1535). J. Szujski (ed.). In: Scriptores Rerum Polonicarum 2. Kraków.

\section{Bibliography}

Bołdyrew A. 2011. Piechota zaciężna w Polsce w pierwszej połowie XVI wieku. Warszawa.

Bołdyrew A. 2014. Kultura militarna pogranicza na przełomie średniowiecza i nowożytności (na przykładzie Królestwa Polskiego). In: A. Olejko, J. Ślipiec, P. Korzeniowski, K. Mroczkowski (eds.), Kresy, granice i pogranicza w historii wojskowej. Oświęcim, 550-557.

Bołdyrew A. 2015. Armatury orszańskie 1514 roku. „Biblioteka Epoki Nowożytnej” 3, 153-172.

Gündüz G., Yaman B. 2013. Anatomy of Wooden Core of Ottoman Composite Archery Bows. „Sains Malaysiana” 42 (5), 547-551.

Kaczanowski P., Kozłowski J. K. 1998. Najdawniejsze dzieje ziem polskich (do VII w.). Kraków.

Korzon T. 1912. Dzieje wojen i wojskowości w Polsce 3. Dokończenie epoki przedrozbiorowej. Kraków.

Moździoch S. 1999. Wstęp. In: S. Moździoch (ed.), Centrum i zaplecze we wczesnośredniowiecznej Europie Środkowej, Wrocław, 7-8.

Spieralski Z. 1958. Polska sztuka wojenna w latach 1454-1562. Warszawa.

Spieralski Z., Wimmer J. 1961. Polska sztuka wojenna w latach 1563-1647. Warszawa.

Swoboda A. 2011. Sztuka postugiwania się krótkim tukiem refleksyjnym za pomoca pierścienia łuczniczego. Gdynia.

Werner J. 1967. Łuk refleksyjny i jego okazy w zbiorach krakowskich. „Studia do Dziejów Dawnego Uzbrojenia i Ubioru Wojskowego" 3, 5-25.

Werner J. 1974. Polska broń. Łuk i kusza. Wrocław.

Żygulski Z. jun. 1982. Broń w dawnej Polsce na tle uzbrojenia Europy i Bliskiego Wschodu. Warszawa. 


\section{Streszczenie}

\section{Luk na pograniczu w XVI w.}

Po zakończeniu długotrwałego konfliktu z państwem krzyżackim $(1521,1525)$ polska polityka zagraniczna skierowała swą uwagę na wschód, co zaowocowało potrzebą przynajmniej częściowej reorganizacji sił zbrojnych. Przełożyła się ona na zmiany między innymi w technice wojskowej. Ta zaś musiała stopniowo być dostosowana do panującej na wschodnim i południowo-wschodnim teatrze działań wojennych specyficznej kultury militarnej. Wśród wielu przejawów tych przemian kilka można zaobserwować w obrębie uzbrojenia. Był to naturalny proces uchwytny w innych kontekstach terytorialnych i czasowych, który zachodził zazwyczaj po zetknięciu się dwóch odmiennych obyczajów wojennych. W realiach XVI w. i wschodniego oraz południowo-wschodniego teatru działań wojennych doskonałym przykładem jest odejście, a następnie powrót do bojowego użycia łuku. Choć wielokrotnie źródła donoszą o przewadze ręcznej broni palnej na polu walki, to łuk nadal był masowo używany nie tylko przez lekką jazdę Wielkiego Księstwa Moskiewskiego oraz Tatarów, ale również przez żołnierzy polskich. Ilość tego typu uzbrojenia w rękach polskich kombatantów walczących w XVI w. zasługuje na analizę, zwłaszcza, że zazwyczaj w opracowaniach z zakresu historii wojskowości łuk jest pomijany jako broń mało skuteczna, czemu zdają się przeczyć nowsze ustalenia na ten temat. 
